\title{
AUTOR DE CONSCIÊNCIA E AUTOR POR CONVICÇÃO: ANÁLISE DA CULPA JURÍDICO-PENAL ${ }^{1}$
}

\section{Roziméri Aparecida Rigon Pedroso²}

Resumo: Em alguns países europeus tem sido dada alguma relevância no ordenamento jurídicopenal às fig uras autor de consciência e autor por convicção, por conta da garantia constitucional do direito à liberdade de consciência. Uma das problemáticas que envolve o tema sub examine é no sentido de tentar saber quais são os limites constitucionais da liberdade de consciência frente a lesão de um bem jurídico consubstanciado em direito fundamental de outra pessoa. Por outro lado, questiona-se se uma ação com fulcro numa decisão de consciência ou por convicção pode encontrar uma justitificação quando configure um ilícito penal?

Palavras-chave: Consciência. Convicção. Direito. Liberdade. Culpa. Ilícito penal. Justificação.

\section{INTRODUÇÃO}

Muito embora a liberdade fundamental de consciência esteja assegurada pelos países democráticos, poucos foram os

1 O presente trabalho, adaptado para este fim, é fruto de um estudo desenvolvido na disciplina de Direito Penal, no curso de Mestrado em Direito, na área de especialização em Ciências Jurídico-Criminais, da Faculdade de Direito da Universidade Clássica de Lisboa, durante o ano letivo 2006/2007.

2 Doutoranda em Direito pela Faculdade de Direito da Universidade de Lisboa; Mestre em Ciências Jurídico-Criminais pela Faculdade de Direito da Universidade de Lisboa; Pós-graduada em Direito Ambiental pela Universidade Federal de Santa Catarina; Especialista em Mediação e Arbitragem pela Universidade Federal de Santa Catarina; Advogada. E-mail: adv0083@hotmail.com 
que levantaram a celeuma em torno da figura do autor por convicção e autor de consciência. Apesar das diversas teorias desenvolvidas sobre esta temática desde o século XIX por estudiosos alemães e, na atualidade, principalmente por estudiosos portugueses e espanhóis, tal questão continua a merecer a devida atenção, mormente por se tratar de tema complexo e ainda muito controverso na doutrina.

A discussão em torno do autor por convicção ou criminoso por convicção, surgiu com a escola positivista, mas o grande impulsionador deste tema foi o alemão Gustav Radbruch. ${ }^{3}$ O questionamento que se fez naquela época foi no sentido de procurar saber se o ordenamento jurídico-penal pode estabelecer para o autor que atua com base em convicções éticas, políticas ou filosóficas uma disposição especial e uma execução especial de pena que não atinja a sua honra? Em outras palavras, hoje poderíamos formular a seguinte pergunta: a decisão por convicção e a decisão de consciência podem afastar a tipicidade ou excluir a ilicitude do fato ou, ainda, excluir a culpa do autor? ${ }^{4}$

No presente estudo tentar-se-á dar uma resposta a estas questões por meio de uma análise crítica às teorias de Gustav Radbruch, Augusto Silva Dias e de Jorge Figueiredo Dias, bem como através da análise de casos práticos trazidos à baila no presente estudo.

\section{AUTOR (CRIMINOSO) COMUM; AUTOR (CRIMINOSO) POR CONVICÇÃO E AUTOR (CRIMINOSO) DE CONSCIÊNCIA: DIFERENCIAÇÃO}

Objetivando uma melhor compreensão do assunto tornase necessário primeiramente traçar em poucas linhas a distinção entre autor comum, autor de consciência e autor por convic-

3 Nota de Augusto Silva Dias, A relevância jurídico penal das decisões de consciência, Coimbra: Almedina, 1986, p.13.

4 Neste ponto seguimos as pegadas de Silva Dias, A relevância...., 1986, pp.13-15. 
ção. ${ }^{5} \mathrm{Na}$ definição de Silva Dias, o autor comum é aquele que normalmente está em contradição consigo mesmo e reconhece, por conseguinte, a norma jurídica que viola. Em contrapartida, o autor por convicção e o autor de consciência não estão em contradição consigo próprios, uma vez que agem segundo as suas convicções, a sua consciência, conforme as suas visões de mundo, rejeitando a ordem jurídica, por entenderem ser contrária ao seus entendimentos, às suas crenças, aos seus princípios éticos e morais. ${ }^{6}$ No mesmo sentido, e seguindo agora o conceito delineado por Correia, o autor por convicção é aquele «(...) que tem consciência do caráter proibido do ato mas, em nome de uma certa convicção política, religiosa ou social, nega a natureza criminosa do comportamento que leva a cabo, substituindo a sua à valoração legal».?

Aqui, faremos um esforço para tentar traçar a distinção entre autor de consciência e autor por convicção, embora não seja uma tarefa fácil. Silva Dias estabelece uma conexão dos «crimes de consciência», com a história dos criminosos por convicção, reportando-se aos fatos praticados com base numa decisão de consciência que, por sua vez, estão ligados ao autor de consciência ou ao autor por convicção. ${ }^{8}$ A doutrina em geral, ${ }^{9}$ muito embora procure ilustrar as duas figuras com exemplos distintos não define claramente os diferentes conceitos de autor de consciência e autor por convicção e, em alguns casos, até confunde as duas figuras. Assim sendo, na busca de uma melhor definição para estas duas figuras, servimo-nos do conceito formulado por Greffenius,${ }^{10}$ ao dizer que o autor por convicção tanto pode ser

5 Em substituição à expressão «criminoso» utilizada por muitos Autores, preferimos nos servir neste estudo da terminologia «autor» que segue o mesmo sentido da figura invocada.

6 Cf, SILVA DIAS., Augusto. A Relevância ....,1986, p. 14 -15.

7 Cf. CORREIA, Eduardo, Direito Criminal. Vol. II. Coimbra: Almedina, 1965, p.331.

8 Cf. SILVA DIAS, Augusto, A relevância..., 1986, p.13.

9 Assim, FIGUEIREDO DIAS, Jorge, O problema da consciência da ilicitude em direito penal, Coimbra: Coimbra Ed, 1978; CORREIA, Eduardo, Direito Criminal, Vol. II, Coimbra: Almedina, 1965: SILVA DIAS, Augusto, A relevância...., 1986.

10 Cf. Greffenius, Günter, apud, SILVA DIAS, Augusto, A relevância..., 1986, p. 147. 
aquele que tem consciência de não lesar nenhuma norma, seja porque não a conhece ou porque a considera inválida (o qual ele denomina de autor por convicção jurídica), ou ainda, aquele que se sente obrigado a agir por força da sua convicção particular, mas não porque desconhece as normas legais ou as considera inválidas (autor por convicção extrajurídica). Portanto, «na mera convicção a ação é sentida como necessária para alcançar um determinado fim, ou seja, se quero $X$ então tenho de fazer $Y_{\star} .{ }^{11}$

Quanto às decisões de consciência, Silva Dias afirma que estas são tomadas ante um dever moral, por respeito às leis universais. Nesta hipótese surge um conflito entre um dever moral e um dever jurídico. Para este Autor, na decisão de consciência a convicção do agente resulta do respeito pelos princípios práticos que norteiam a eleição universal, isto é, "posso moralmente aceitar para mim próprio a decisão que tomei». ${ }^{12} \mathrm{O}$ argumento principal deste Autor é o de que «a diversidade de dimensão não impede a inter-relação das figuras autor de consciência e autor por convicção, na medida em que as decisões morais, constituem uma possibilidade real de efetivação moral das convicções». ${ }^{13}$ Isto suscita a primeira dúvida: estas duas figuras, autor por convicção e autor por consciência estariam de fato dentro de uma mesma categoria? Os crimes por convicção em sentido amplo, abrangem os crimes de consciência ou vice-versa?

No nosso entendimento não há que confundir autor de consciência com autor por convicção. E fazemos tal afirmação assente na ideia de que a nossa consciência é o nosso núcleo mais secreto; ela é o juízo crítico sobre os nossos atos. A motivação da nossa consciência, no nosso modo de ver, não é oferecida pela religião, não exige igualmente uma crença no Céu ou no Inferno, mas decorre de uma lei natural universal. Exemplificando, nós podemos ser seguidores do budismo ou hinduísmo, católicos, protestantes ou testemunhas de geová, podemos ser partidários da política da esquerda ou da direita, podemos

11 Cf. SILVA DIAS, Augusto, A relevância..., 1986, p.60.

12 Cf. SILVA DIAS, Augusto, A relevância..., 1986, pp. 55-56.

13 Cf. SILVA DIAS, Augusto, A relevância..., 1986, pp.63-64. 
pertencer a esta ou aquela etnia, falar inglês, chinês, árabe ou português, todavia, o quadro de princípios ou valores é sempre o mesmo, decorre sempre da natureza do próprio homem. A consciência do homem é a mesma em qualquer canto do nosso planeta. A nossa consciência, em seu sentido mais amplo (consciência moral), é a faculdade de distinguirmos o bem do mal, donde deriva a obrigação moral de realizar o bem.

Quando Kant afirmou um dia: «examinas seriamente as máximas da tua ação de modo que possas transformá-las em leis universais», ${ }^{14}$ ele quis simplesmente dizer que considera-se uma ação moral apenas aquela que pode ser convertida em lei universal, isto é, a universalidade da ação deve ser a característica lógica dos juízos de consciência. Assim, sufragamos o entendimento de Silva Dias, quando afirma que a nossa consciência moral é um elemento constitutivo, uma faculdade essencial à nossa natureza racional. Mas esta faculdade não é empírica, ela não é uma espécie de sentido ou de instinto mais ou menos cego, mas sim a própria razão ordenando os atos da nossa vida.

Prosseguindo no campo das definições das figuras em análise, por seu turno, o autor por convicção é aquele que possui uma certa fé ou crença, um conjunto de normas e valores próprios que orientam o seu comportamento na sua vida privada. Ao contrário da consciência, as convicções podem perecer, podem cair por terra com o passar do tempo, a exemplo de um caso ilustrado na obra de Kant, do inquisidor que condenava à morte o herege, porque ele acreditava numa vontade divina que impunha o dever de destruir a heresia e o herege. $O$ inquisidor era considerado por Kant como um autor por convicção, em dois sentidos: tanto objetivo como subjetivo primeiro, porque esta convicção não poderia converter-se em lei universal, pois assentava numa crença histórica que contrariava os puros princípios morais; segundo, por não estar realmente convencido da justeza e da verdade daquela regra do evange1ho. ${ }^{15}$ Isso corrobora com a ideia defendida por Silva Dias, a de

14 KANT, Immanuel, Crítica da razão prática. Trad. A. Morã, Edições 70, 1984, p.185. 15 KANT, Immanuel, Crítica da razão ..., 1984, p. 203. 
que sentir-se obrigado a atuar, é, do ponto de vista moral , algo muito diferente do ter a obrigação de atuar. ${ }^{16}$

Em síntese, podemos concluir que o autor por convicção pode agir consciente ou inconscientemente, numa manifestação puramente psicológica, mas o autor de consciência, pelas razões já expostas anteriormente, não pode agir inconsciente de sua própria consciência, dos seus valores éticos e morais. $\mathrm{O}$ valor de uma decisão de consciência é absoluto, cremos nós (nesse ponto concordamos novamente com Silva Dias), quando essa decisão se limita a proclamar os princípios universais da moralidade; quando ela visa a atingir o bem de toda a coletividade. Tudo o que for diferente disso deve ser considerado um valor relativo, pessoal, e, portanto, estar-se-á frente a um autor por convicção e não diante de um autor de consciência.

Num rápido golpe de vista e numa conclusão provisória, parece-nos que a confusão entre as duas figuras, autor por convicção e autor por consciência, reside numa ausência de diferenciação dos conceitos de heteronomia e autonomia da consciência e, não só, mas inclusive nos conceitos psicológicos e ético/morais de consciência. Boa parte da doutrina já referenciada trata, portanto, as duas figuras (autor por convicção e autor por consciência) de uma forma genérica, englobando-as no tipo autor por convicção, que nada mais é do que aquele que possui uma motivação política, ética ou religiosa para a sua ação. Tecidas tais considerações, convém agora falarmos sobre o pensamento de Radbruch. É o trajeto a seguir.

\section{TEORIAS FILOSÓFICAS-JURÍDICO-PENAIS EM DISCUSSÃO}

\subsection{Teoria de Gustav Radbruch: relativismo e separação entre moral e direito}

No início da sua carreira jurídico-política-filosófica, Radbruch, apresentou-se como juspositivista, mas a experi-

16 Cf. SILVA DIAS, Augusto, A relevância jurídico..., 1986, pp. 40-41. 
ência nacional socialista deixou nele uma certa impressão que o obrigou a repensar o seu anterior "positivismo». Esta reflexão leva-o a rechaçar essa ideia, uma vez que vê na separação entre o direito e a moral a base em que se apoiou o nazismo para levar a cabo, sob a aparência da legalidade, as maiores injustiças. Isto incita-o a sustentar que uma lei que contrarie os princípios básicos da moralidade não é direito, ainda que esta lei seja formalmente válida. ${ }^{17}$

Opondo-se ao monismo metodológico de Kelsen, Radbruch promove uma contemplação do direito por dois lineamentos. O primeiro refere-se ao dualismo metodológico, o qual traduz-se na distinção entre dois cosmos da realidade, consubstanciados na separação entre moral e direito; o segundo referese ao relativismo, ao afirmar que as diversas formas de pensar têm fulcro na diversidade dos homens e, desse modo, torna-se impossível a construção de convicções uniformes. A construção do pensamento filosófico de Radbruch está alicerçada em três maneiras de encarar o direito: a) atitudes que referem realidades jurídicas a valores, considerando o direito como fato cultural (atitude essencial da ciência do direito); b) atitude valorativa que considera o direito como valor de cultura (atitude precípua da filosofia do direito) e; c) atitude superadora dos valores (tema da filosofia religiosa do direito). Em suma, a ideia de direito em Radbruch é construída na análise conjunta de três elementos principais: justiça, fim e segurança social. ${ }^{18}$

Sendo assim, para Radbruch, ao mesmo tempo que a ideia de direito se assenta na justiça como valor universal, esta é passível de alterações face aos interesses políticos de determinada época de sua positivação. Com efeito, esta positivação não garante de forma absoluta uma estabilidade social, pois o direito, segundo este Autor, pode variar tanto com o fim relati-

17 RADBRUCH, Gustav, Filosofia do Direito. Coimbra: Coleção Stvdivm. Trad. Cabral de Moncada, Arménio Amado Editora, 1974.p. 165 e ss.

18 Cf. RADBRUCH, Gustav, Filosofia do ....,1974, p. 186 e ss. 
vista em que é observado quanto com os costumes de cada comunidade. Como já dissemos no início deste estudo, Radbruch foi quem reacendeu a discussão acerca do autor (criminoso) por convicção, conforme ficou evidenciado no seu projeto do Código Penal Alemão apresentado em 1922. ${ }^{19}$

No parágrafo 71 do referido projeto, Radbruch propôs que ao autor por convicção fosse aplicada, no lugar de certas penas de prisão, uma pena de simples detenção ou custódia, não desonrosa, se «o motivo determinante consistisse numa convicção ética, religiosa ou política, com base na qual o agente se sentiu obrigado à prática do fato». ${ }^{20}$ Tal pensamento foi aceite durante algum tempo na ordem jurídica alemã, mas o surgimento da moderna política criminal deitou por terra toda a possibilidade de se conceder privilégios discriminatórios aos autores por convicção face a aplicação de uma pena não privativa de liberdade. Por isso consagrou-se uma única e simples pena privativa de liberdade.

Radbruch sustenta que o Direito justo não é conhecível, nem demonstrável, o que torna a «decisão do legislador um ato de vontade e de autoridade e não um ato de verdade. $\mathrm{O}$ indivíduo é obrigado a obedecer a lei, mas não tem o dever de obedecê-la. Um dever só pode afirmar-se quando o comando ou proibição é subjetivamente reconhecido». ${ }^{21}$

Radbruch afirma que o autor por convicção que não cumpre as regras de conduta penal é alguém que pensa de maneira diferente. Ele age de acordo com uma visão do mundo que não aceita as regras impostas pelo Estado. Dessa maneira, este Autor

19 Este projeto foi escrito por Gustav Radbruch quando ele ainda exercia a função de Ministro da Justiça da República Weimer. Ele tinha a esperança de que tal projeto fosse aprovado pelo Parlamento e entrasse em vigor antes das eleições de 1924. Mas os seus esforços não renderam frutos. GUSTAV RADBRUCH. EI delincuente por Convicción. Revista Eletrônica de Ciência Penal Y Criminologia, 2005. $n^{\circ} 5$. Trad. Guzmán Dalbora e José Luís. p. 93 e ss.

20 Cf. RADBRUCH, Gustav, apud SILVA DIAS, Augusto, A relevância jurídico..., 1986, p., 98 e ss.

21 Cf. RADBRUCH, Gustav, apud SILVA DIAS, Augusto, A relevância jurídico..., 1986, p. 14. 
sustenta que a imposição de pena de prisão não comporta qualquer valoração ética da honra do autor por convicção, ao contrário, a pena de prisão por possuir caráter infamante não cumpre os fins assinalados. E ele vai mais além quando diz que o autor por convicção é alguém que não precisa ser corrigido e não resulta merecedor de retribuição, mas tão somente alguém que pensa de forma diferente. Portanto, o autor por convicção política, religiosa e moral merece um tratamento especial, pois toda a convicção de um dever é, por necessidade conceptual, de índole moral, e os campos dos deveres políticos e religiosos são apenas âmbito de ação de convicções éticas. ${ }^{22}$

O entendimento de Radbruch consubstancia-se então na aplicação de uma pena especial para o autor por convicção, pena que não seja desonrosa. No entanto, a tese deste Autor não se sustentou por muito tempo, pois o entendimento majoritário da doutrina alemã seguia no sentido de que a criação de uma pena de privação de liberdade honrosa atribuiria às outras penas de prisão um caráter infamante, na medida em que contrariava o pensamento de ressocialização. ${ }^{23}$ Vejamos agora o entendimento de Silva Dias.

\subsection{Teoria de Augusto Silva Dias: «A Relevância jurídico penal das decisões de consciência»}

Iniciando a abordagem do estudo desenvolvido por Silva Dias acerca desta matéria, destacamos aqui apenas alguns tópicos que julgamos mais interessantes para este debate, sem desconsiderar a relevância do seu estudo como um todo. Baseando-se numa extensa bibliografia, na sua grande maioria referências doutrinárias germânicas, o Autor buscou traçar em sua obra os mais diversos entendimentos filosófico-jurídico-penais acerca das decisões de consciência abrangendo, inclusive, as decisões

22 RADBRUCH, Gustav, apud SILVA DIAS, Augusto, A relevância jurídico..., 1986, pp.14 ess.

23 Cf. SILVA DIAS, Augusto, A relevância jurídico..., 1986, pp.14 -20. 
por convicção. Eis então algumas considerações deste Autor acerca das figuras autor de consciência e autor por convicção.

Com relação ao comportamento do autor de consciência, Silva Dias leciona que não é possível encontrar qualquer justificação jurídico-penal se configurar lesão de um bem jurídico individual consubstanciado um direito de terceiro, pois o conflito entre a consciência individual e a ordem jurídica Estatal não pode ser dirimido no âmbito da ilicitude. A garantia jurídica da liberdade de consciência vincula o Estado a oferecer alternativas jurídicas sempre que uma norma jurídica obrigue os indivíduos a um comportamento contrário à sua consciência, e desde que não esteja em causa o direito de outrem, o indivíduo tem o direito de agir conforme a sua decisão de consciência ${ }^{24}$.

Quanto ao autor por convicção, este estudioso argumenta que as ações decorrentes de uma decisão por convicção, quando caracterizam uma lesão do direito alheio, não estão protegidas pela garantia constitucional do exercício da liberdade de consciência, isso porque o fato praticado unicamente com base numa crença configura-se num ilícito penal e, nesta hipótese, o autor por convicção não pode invocar, em se tratando do ordenamento jurídico português, o artigo $41 .^{\circ}$ da Constituição da República Portuguesa, pois o que este enunciado não justifica, também não tem o condão de invocar uma causa de desculpa. A culpa jurídica, diz este Autor, «é independente da culpa moral tanto no sentido de moral autónoma como no de moral heterônoma». ${ }^{25}$

Silva Dias fundamenta tal assertiva, dizendo, em primeiro lugar, que em havendo uma separação entre a ordem ética e a ordem jurídica, as normas jurídicas são sempre obrigatórias, mesmo que tais normas não se apresentem ao indivíduo como deveres morais; em segundo plano, porque a culpa jurídicopenal estabelece-se por padrões jurídicos, de natureza formal e;

24 Cf. SILVA DIAS, Augusto, A relevância jurídico..., 1986, pp. 106, 110 e 130. 25 Cf. SILVA DIAS, Augusto, A relevância jurídico..., 1986, pp.139 e 141. 
por último, «a culpa jurídico-penal é culpa jurídica porque é publicamente comprovada perante a barra de um tribunal de acordo com um processo jurídico». Desta forma, o autor por convicção, independentemente de a Lei ser justa ou injusta, incorre, a priori, sempre em culpa jurídica. A culpa só poderá ser excluída se não estiver presente um dos seus elementos, ou seja, a capacidade de culpa ou a consciência da ilicitude.

$\mathrm{Na}$ busca de uma melhor explicação sobre este assunto, Silva Dias traça uma distinção doutrinal entre autor por convicção «jurídica» e autor por convicção de dever, ou ainda, autor por convicção «extrajurídica». $\mathrm{O}$ autor por convicção jurídica é aquele que, em consciência, pensa não lesar nenhuma norma, seja porque ele desconhece a norma legal ou porque a julga inválida, mesmo que na prática esta norma seja totalmente válida e, neste caso, poderia configurar erro sobre a ilicitude do fato. Exemplo trazido à baila pelo Autor é o da testemunha de geová que não conduz o indivíduo acidentado ao hospital ou não lhe presta socorro porque considera não ser obrigada a agir, em atenção ao preceito constitucional que lhe confere o direito de agir segundo a sua consciência. Em contrapartida, o autor por convicção «extrajurídica» sente-se obrigado a agir por força da sua convicção pessoal e não porque não conhece as normas legais vigentes ou as considere inválidas ou injustas. Nesta hipótese, não há que se considerar a aplicação do erro sobre a ilicitude, e muito menos qualquer eventual relevância do problema na seara dos elementos de culpa. ${ }^{26}$ Defende Silva Dias que o Estado deve procurar evitar tanto quanto possível o surgimento de conflitos entre o dever moral (decisão de consciência) e um dever jurídico (norma jurídica).

Um dos instrumentos de proteção ao direito de liberdade de consciência pode ser encontrado tanto na legislação interna como na legislação internacional, ${ }^{27}$ e a função político-social-

26 Cf. SILVA DIAS, Augusto, A relevância jurídico..., 1986, p., 146.

27 Cf. CRP, Art.41. ${ }^{\circ}, n^{\circ} 1$ : «A liberdade de consciência, religião e de culto é inviolável. No mesmo sentido segue a Constituição da República Federativa do Brasil. Art. $5^{\circ}$, VI. É inviolável a liberdade de consciência e de crença (...)»; e Art. $5^{\circ}$, VIII. 
participativa de tais instrumentos normativos é «o de fomentar a corresponsabilidade dos cidadãos indispensável para a vida social, criando assim a possibilidade de o Estado ser sustentado pelos seus cidadãos e por esta via democraticamente legitimado». ${ }^{28}$ Desta maneira, a garantia jurídica da liberdade de consciência obriga o Estado a oferecer alternativas jurídicas, sempre que uma norma jurídica obrigue os indivíduos a um comportamento contrário à sua consciência.

No que se refere ao artigo 41. ${ }^{\circ}$ da Constituição Portuguesa, Silva Dias manifesta sua posição afirmando que a norma sob exame exige uma análise do problema na teoria da norma e não na teoria da pena, isto é, ao nível de pressupostos e não ao nível da punibilidade. Dentro dos pressupostos da punibilidade, o art.41. ${ }^{\circ}$ projeta a sua influência sobre a ilicitude e não sobre a culpa. O exercício da liberdade de consciência prende-se com a delimitação do âmbito das exigências que o direito penal faz à conduta dos cidadãos. Quem, cumprindo os ditames da sua consciência, age dentro do âmbito de proteção da norma constitucional atua de acordo com o direito - isto é, a ilicitude do comportamento fica excluída.

Dito isso, passamos agora ao entendimento de Jorge Figueiredo Dias sobre esta matéria.

«Ninguém será privado de direitos por motivo de crença religiosa ou de convicção filosófica ou política, salvo se as invocar para eximir-se de obrigação legal a todos imposta (...)». Têm-se ainda: Declaração Universal dos Direitos do Homem, Art.18०: "Toda a pessoa tem direito à liberdade de pensamento, de consciência e de religião (...)»; Pacto Internacional dos Direitos Civis e Políticos, Art.18 ${ }^{\circ}, \mathrm{n}^{\circ}$ 1.: «Toda e qualquer pessoa tem direito à liberdade de pensamento, de consciência e de religião (...)»; Art. $18^{\circ}, \mathrm{n}^{\circ} 2$. «Ninguém pode ser objecto de pressões que atentem à sua liberdade de ter ou adoptar uma religião ou uma convicção da sua escolha»; Convenção Européia dos Direitos do Homem, Art. $9^{\circ}, \mathrm{n}^{\circ} 1 .$. "Qualquer pessoa tem direito à liberdade de pensamento, de consciência e de religião (...) Restrições: A liberdade de manifestar a sua religião ou convicções, individual ou colectivamente, não pode ser objecto de outras restrições senão a que, previstas na lei, constituírem disposições necessárias, numa sociedade democrática, à segurança pública, à protecção da ordem, da saúde e moral públicas, ou à protecção dos direitos e liberdades de outrem». Disponível em: http://www.gddc.pt/direitoshumanos/textos-internacionais-dh/regionais.html e http://www.gddc.pt/direitoshumanos/index-dh.html. (sublinhado nosso).

28 Cf. SILVA DIAS, Augusto, A relevância jurídico..., 1986, pp., 57-58. 


\subsection{Teoria de Jorge de Figueiredo Dias: «Dos fatos de convição aos fatos de consciência: uma consideração jurídico-penal»}

Figueiredo Dias levanta a problemática em torno destas figuras argumentando que na atualidade o debate reside essencialmente entre a seara jurídico-penal e o meio jurídico-constitucional, frente a questão das limitações das garantias constitucionais. Ao partilhar o pensamento de Correia, Figueiredo Dias entende que simples convicções de ordem subjetiva não possuem o condão de emprestar à conduta que delas emane um conteúdo social com um sentido capaz de as diferenciar daquelas outras que, de acordo com o pensamento legislativo, entram na área de proteção da norma incriminadora. Não podem, igualmente, tais convicções serem valoradas pelo Estado a um nível extremamente superior ao valor do bem jurídico lesado pela conduta, nem tão pouco justificar a renúncia pela ordem jurídica à proteção dos bens jurídicos postos em causa pela conduta. A convicção subjetiva do agente não pode, em caso algum, excluir a ilicitude do fato e nem a culpa do agente. ${ }^{29}$ Neste ponto, este Autor sufraga o entendimento de Silva Dias, ao afirmar que a culpa jurídico-penal é coisa bem diversa da culpa ética. ${ }^{30}$

Para Figueiredo Dias, uma simples convicção moral, religiosa, política ou social não possui em si mesma a força de afastar a própria censura ética, exceto dentro de um subjetivismo ético

29 Citando um exemplo de um mero fato de convicção subjetiva, o «de um juiz que comete o crime de violação de segredo de deliberação e votação em processo penal, por estar eventualmente convencido de que a proibição de declaração de voto não constitui a melhor solução jurídico-processual ou conforma mesmo uma norma juridicamente inválida» (RPCC 5, 1995, p.4254 e ss). Exemplo trazido por FIGUEIREDO DIAS em sua obra: Temas Básicos da Doutrina Penal. Coimbra: Editora Coimbra, 2001., p.311- 313.

30 «A culpa jurídica é, quanto a nós, independentemente da culpa moral tanto no sentido de moral autónoma como no de moral heterônoma. (...) A lei injusta não deixa de ser Lei válida e a sua violação de implicar uma censura de culpa jurídica. Se admitíssemos no entanto que a lei injusta não é lei, então o facto que formalmente a lesasse nem sequer seria ilícito».Cf. SILVA DIAS, Augusto, A relevância jurídico..., 1986, pp.141-142. 
exasperado, «que não serviria nunca para ligar a culpa jurídicopenal a uma culpa ética no sentido predito; pelo que a força de uma convicção eximente da culpa jurídico-penal só poderia ser considerada se determinasse uma causa legal de exclusão da culpa». ${ }^{31}$ Assim, este Autor argumenta que a convicção deve ser levada em conta tão somente na teoria da medida da pena e nem sempre e necessariamente a favor do convicto. Convicções, das mais diversas, seja em matéria política, religiosa, moral e social, muitas delas às vezes divergentes das normas jurídicas, toda as pessoas as têm, e o princípio democrático da tolerância obriga o Estado a respeitá-las. ${ }^{32}$

Quanto ao autor por convicção, percebe-se que Figueiredo Dias não diverge da tese de Silva Dias e de Radbruch, exceto, já o dissemos no parágrafo anterior, quando afirma que os fatos por convicção só podem influenciar na medida da pena e nem sempre a favor do agente, ao contrário de Silva Dias que defende que quando o autor por convicção não possui consciência da ilicitude, isto é, quando entende que a sua decisão possui amparo legal, então deve ser considerado erro sobre a ilicitude do fato.

Referindo-se à outra figura, o autor de consciência, Figueiredo Dias parte do seguinte questionamento: «a lei jurídica continua válida e vigente mesmo perante uma decisão de consciência que a contraria, ou se, pelo contrário, uma tal validade e vigência está submetida à reserva de uma cláusula de consciência»? ${ }^{33} \mathrm{Na}$ opinião deste Autor, não há uma resposta à esta questão porque não se sabe qual a exata amplitude do privilégio jurídico-constitucional da liberdade de consciência, e muito menos qual o nível da doutrina geral do crime aquele privilégio releva, se a nível do tipo, da ilicitude, da culpa, da punibilidade ou da pena. Assim, se toda a decisão de consci-

31 Segue o mesmo raciocínio ROXIN, Claus A culpabilidade e sua exclusão no Direito Penal. Revista Brasileira de Ciências Criminais. São Paulo: Revista dos Tribunais, n. ${ }^{\circ} 46,2004$, p. 46-72.

32 Cf. FIGUEIREDO DIAS, Jorge, Temas básicos...., 2001, p. 315.

33 Cf. FIGUEIREDO DIAS, Jorge, Temas básicos...., 2001, p.318. 
ência tivesse o amparo da garantia constitucional da liberdade de consciência, então nenhum fato praticado por decisão de consciência acarretaria a responsabilidade jurídico-penal do indivíduo. Por outro lado, a própria decisão de consciência que originou o fato contrário à norma legal tornar-se-ia uma causa de justificação. ${ }^{34}$

Seguindo as pegadas de Roxin, Figueiredo Dias argumenta que proteger a liberdade de consciência não pode significar o sentido de que o Estado deva fazer sua a decisão de consciência individual, quando ela, na verdade, se afasta da lei estatal, pois se uma lei constitucional de qualquer país inscreveu a liberdade de consciência não apenas entre os seus princípios de tolerância e compreensão, através do modo de pensar e atuar da pessoa no meio social, «mas tão apenas entre os direitos, liberdades e garantias fundamentais da pessoa, então isso só pode significar que quem a exerce não comete em caso algum um ilícito penal. Porquanto, a manifestação da liberdade de consciência encontra o seu limite imanente na prática de um crime». ${ }^{35}$

$\mathrm{O}$ ato praticado com base numa decisão de consciência, sempre que configure um ilícito penal, constitui um fato típico, antijurídico e culpável, e não pode ser invocada a prerrogativa jurídico-constitucional de liberdade de consciência para excluir a culpabilidade do agente. Todavia, em casos excepcionais, quando o fato tiver uma específica motivação, o de provir da consciência ética do agente e desde que este por não seguir a voz da sua consciência venha a sofrer danos irreparáveis na sua personalidade, então o fato penal, apesar de típico, antijurídico e culpável, pode constituir uma causa de exclusão de culpa

$34 \mathrm{O}$ problema reside no fato de se saber de que maneira esta liberdade fundamental de consciência, assegurada tanto na ordem interna como externa se reflete sobre as decisões de consciência, quer seja no sentido de configurar, de limitar ou repelir qualquer relevância jurídico-penal dos fatos, de outra forma puníveis, que delas emanem. No entendimento de Figueiredo Dias a solução para esta questão está longe de ser encontrada, mormente porque ainda não se sabe qual o real sentido da garantia constitucional de liberdade de consciência, assim como o de determinar qual o estágio da teoria geral do crime que essa garantia leva em conta. Cf. FIGUEIREDO DIAS, Jorge, Temas básicos...., 2001, p. 320.

35 Cf. FIGUEIREDO DIAS, Jorge, Temas básicos...., 2001, pp. 330 e 332. 
(desculpa), prevista no artigo 31. ${ }^{\circ}$ 2-b do Código Penal Português. Contrariando a tese de Silva Dias, este Autor conclui o seu pensamento afirmando que ao autor de consciência o que não falta é a consciência da ilicitude, e ainda, que se atribui um campo demasiado extenso ao direito constitucional da liberdade de consciência e se «concede ainda um campo demasiado estrito a uma específica e autónoma consideração jurídico-penal dos fatos de consciência». Portanto, o postulado máximo deste Autor é a ideia de desconstitucionalização dos fatos de consciência, pois só assim, talvez, se encontre uma «justa e adequada consideração quando conduzem à prática de um fato penal». ${ }^{36}$

\section{ANÁLISE DE CASOS PRÁTICOS}

Com apenas algumas alterações de nomenclatura, posto que o conteúdo é o mesmo, vamos nos servir primeiramente de um exemplo trazido à lume por Silva Dias.

João, durante o período de cumprimento do serviço militar adere a um movimento pacifista, tornando-se-lhe cada dia mais insuportável continuar a prestar os serviços militares, porquanto o serviço militar era para ele o exercício de práticas destinadas à violência. Após vários pedidos de dispensa do serviço lhe terem sido negados, João, ciente das consequências jurídico-penais, resolve em consciência desertar. Como todas as hipóteses de objeção de consciência contempladas na Lei Portuguesa $\mathrm{n}^{\circ} .6 / 85$ se reportam a uma fase prévia de recrutamento, a conduta de João preencheria o tipo legal de crime de deserção previsto no art.142. ${ }^{\circ}$, no 1 -a do Código de Justiça Militar Português. Note-se, porém, que neste exemplo não foi dito que ele seguia algum tipo de religião. Pergunta-se: a conduta de João é punível ou o fato comporta uma causa de exclusão de ilicitude?

36 Cf. FIGUEIREDO DIAS, Jorge, Temas básicos..., 2001, pp.330 - 331 e 335. Tese contrária à de SILVA DIAS, que argumenta que «a inviolabilidade da liberdade de consciência significa que dentro do âmbito da protecção que a Constituição confere ao indivíduo, o Estado não pode interferir no seu exercício. (...) os limites da liberdade de consciência não resultam da lei penal, mas tão somente da Constituição». Cf. SILVA DIAS, Augusto, A relevância..., 1986, p. 69. 
João deve ser considerado um autor de consciência ou um autor por convicção?

Neste exemplo, Silva Dias entende que trata-se de um autor de consciência, pois assenta no dever de respeitar o outro como fim em si mesmo. Não é uma decisão tomada contra ninguém; nela João compromete-se com a universalidade e não em sua oposição. Portanto, a ordem jurídica confere a João o direito de seguir a sua consciência, com todas as implicações que daí advém, desde que a sua ação não resulte em lesão de um direito de terceiro. ${ }^{37}$

Em nossa opinião, e com o devido respeito ao entendimento de Silva Dias, não conseguimos vislumbrar na hipótese apresentada a figura do autor de consciência, isto porque o argumento de João de que aderiu a um movimento pacifista e de que a prestação do serviço militar tornava-se-lhe cada dia mais tormentosa não é suficientemente forte para demonstrar que a continuidade do serviço militar poderia acarretar-lhe danos na sua personalidade. Ora, como já afirmou Figueiredo Dias, a esmagadora maioria das pessoas são pacifistas e adeptas ao não uso de armas. Em condições normais, ninguém será contra a paz. Neste caso, mais parece que João não se adaptou ao serviço militar e, portanto, invocou tais argumentos para se ver livre de uma obrigação que era até então imposta (serviço militar obrigatório) a todos os jovens portugueses. Apesar da conduta de João não resultar em lesão à direitos de terceiros, "poderia abrir precedentes no sentido de outros "camaradas" virem a adotar comportamento semelhante, apelando à proteção constitucional do direito à liberdade de consciência. Isso levaria um bom número de cidadãos a transgredir as regras a todosimposta. Assim, no nosso modo de ver, a conduta de João configuraria o crime de deserção, capitulado no Código de Justiça Militar.

Num segundo exemplo, embora não seja na seara penal, mas de igual forma relevante para a compreensão da temática

37 Cf. SILVA DIAS, Augusto, A relevância jurídico..., 1986, p., 111-112. 
apresentada, trazemos um caso concreto extraído da jurisprudência de um dos Tribunais brasileiros.

A, ajuizou ação de investigação de paternidade contra B, suposto pai da infante $\mathrm{C}$, onde postulou a realização de perícia médica consistente em exame de DNA, tendo sido deferida pelo juízo a quo. Acontece que $\mathrm{B}$ recusou-se à realização do exame, alegando que era testemunha de geová e que a sua religião não permitia realizar coleta de material genético e, ainda, que não podia ser penalizado porque a Constituição lhe assegurava o direito à liberdade de consciência. ${ }^{38} \mathrm{O}$ entendimento do magistrado a quo foi no sentido de que «os direitos individuais, conforme lição elementar da dogmática jurídica não prevalecem quando contrapostos aos direitos sociais, coletivos ou difusos, cujo campo de abrangência é bem maior, e o atendimento milita em favor da igualdade material e da própria pacificação social». $O$ julgador prossegue a sua argumentação afirmando que apesar de o exame pericial (DNA) não ser obrigatório, nem absoluto, é útil ao descobrimento da verdade. Tendo em vista que $\mathrm{B}$ recusou-se à realizá-lo, mesmo depois de evidenciada a sua possibilidade económica de patrociná-lo, tal comportamento só depunha contra si próprio. Em suma, a rejeição de $\mathrm{B}$ em submeter-se ao exame de DNA, não disponibilizando o material genético necessário, fez presumir a paternidade que lhe foi imputada.

Inicialmente, numa análise preliminar dos fatos trazidos à baila, cabe dizer que o sujeito $\mathrm{B}$, ao recusar-se à realização do exame de DNA, com fundamento de que a sua religião não o permitia fazê-lo acabou por restar prejudicado, sendo-lhe imputado a paternidade de C. Se B tivesse seguido a determinação judicial, no sentido de realizar o mencionado exame, mesmo agindo contra a sua crença religiosa, talvez o resultado do exame não confirmasse a paternidade de C. Entretanto, a sua negação fez com que o magistrado lhe imputasse a paternidade, inde-

38 Ac n. 2002.011237-8-Relator: Monteiro Rocha. 17/10/2002. Tribunal de Justiça de Santa Catarina -Brasil. 
pendentemente de confirmação de exame laboratorial, tendo sido considerado neste caso que os interesses de $\mathrm{C}$ deveriam sobrepor-se aos de B. Deixando de lado o mérito desta questão e adentrando tão somente no ponto que nos interessa, em momento algum B poderia ser considerado um autor de consciência, quando muito um autor por convicção.

Imaginemos que a decisão judicial fosse favorável à $\mathrm{B}$, isto é, que o direito de $\mathrm{C}$ fosse posto de lado face ao reconhecimento pelo julgador do direito à liberdade de consciência de $\mathrm{B}$. Ora, se isso acontecesse estar-se-ia diante de uma equivocada interpretação dos direitos fundamentais, e porque não dizer perante uma flagrante injustiça. Em nossa opinião o direito fundamental da liberdade de consciência do indivíduo não deve sobrepor-se, in casu, aos direitos fundamentais da criança, devendo o julgador ponderar os valores em causa. A valoração positiva da liberdade de consciência pela Carta Constitucional dá ao cidadão a liberdade de se comportar em conformidade com os imperativos de consciência, todavia, não se pode permitir uma visão restritiva da norma que, por conta de uma permissão na liberdade de agir de acordo com a consciência, seja pisado outros direitos fundamentais garantidos constitucionalmente. Nestas hipóteses, dever-se-á aplicar o princípio da proporcionalidade, considerando no caso concreto os bens constitucionalmente protegidos, pesando a incidência que cada um deve ter, estando certo que um direito será preterido em relação a outro, pela sua importância no caso em questão. ${ }^{39}$

Num terceiro e último exemplo, temos Tibúrcio, testemunha de Geová, que diante do grave estado de saúde de sua mulher, Maria das Dores, a qual necessita urgentemente de um transplante de rim, não concorda com a transfusão de sangue necessária ao ato, por ser contrário à sua convicção religiosa. Neste exemplo, a decisão de Tibúrcio coloca em perigo a vida de sua mulher, pois embora ela professe a mesma doutrina do

39 Cf. STEINMETZ, Wilson António, Colisão de direitos fundamentais e princípio da proporcionalidade, Porto Alegre: Livraria do Advogado, 2001, pp. 142-143. 
marido, prefere contrariar a sua ordem religiosa e realizar a cirurgia que poderá salvar-lhe a vida. Então, de um lado temos Tibúrcio que não concorda com o procedimento da transfusão de sangue, e de outro econtra-se Maria das Dores, que concorda com o ato médico, mesmo agindo contra a sua crença religiosa. Aqui temos duas hipóteses: Se Tibúrcio e Maria das Dores vivessem nos Estados Unidos da América do Norte, e tivessem algum poder económico, poderiam certamente recorrer ao novo método da medicina que realiza cirurgia sem sangue, procedimento que foi criado pelo Doutor Nicolas Jabbour, da Universidade da Califórnia do Sul para satisfazer inicialmente as necessidades das testemunhas de Geová. ${ }^{40}$ Havendo esta possibilidade, Maria das Dores certamente poderia realizar o procedimento operatório, sem contrariar a sua crença religiosa, bem como a de seu marido Tibúrcio.

Por outro lado, de duas uma ou Maria das Dores autoriza a transfusão de sangue mesmo sem o consentimento de Tibúrcio e assim salva a sua própria vida, ou então não sobreviverá já que os médicos lhe disseram ter apenas mais três meses de vida, caso não realize o procedimento cirúrgico. Recusando-se à realização do ato por mera convicção religiosa de Tibúrcio, e este não apresentando nenhuma alternativa para salvar a vida de sua mulher, certamente seria responsabilizado pelo crime de homicídio por negligência, previsto no art. 137. ${ }^{\circ}$ do Código Penal Português, ou art.121. ${ }^{\circ}, \S 3 \circ$ ou §5 do Código Penal Brasileiro. Tibúrcio não goza de nenhuma proteção do direito à liberdade de consciência, vez que o seu direito de liberdade de consciência termina no exato momento em que começa o direito fundamental de sua mulher, o direito à vida que, apesar de não ser um direito absoluto, é um bem de maior relevância, prevalecendo sobre os demais. ${ }^{41}$ Por isso, a conduta omissiva de Tibúrcio caracterizaria sim um tipo legal de crime e não se poderia falar aqui em exclusão de culpa ou mesmo de desculpa.

40 Para maiores informações ver :http://sol.sapo.pt/blogs/mjcr/default.aspx. Acesso em 12/03/07.

41 Neste sentido, SILVA DIAS, Augusto, A relevância jurídico..., 1986, p.129. 


\section{ANÁLISE CRÍTICA DO PROBLEMA FRENTE ÀS TEORIAS ABORDADAS}

\subsection{Decisão de consciência e decisão por convicção: causa de exclusão da culpa ou desculpa?}

Longe de termos a pretensão de defender qualquer posição contrária ou favorável aos entendimentos esposados neste trabalho, a priori, o que nos parece ter mais sentido de tudo ou do pouco que aqui foi dito, é o de que a problemática em torno das figuras autor por convicção e autor de consciência, aparentemente centra-se no fato de não se ter ainda estabelecido expressamente os limites constitucionais da liberdade de consciência.

Entendemos que o direito à liberdade de consciência tornase relativo (encontra seu limite) sempre que uma decisão de consciência implique na lesão de um bem jurídico consubstanciado em direito fundamental de outra pessoa e, em outras palavras, seguindo os passos de Figueiredo Dias, «a manifestação da liberdade de consciência encontra o seu limite imanente sempre que ela preenche um tipo legal de crime». ${ }^{42}$ Desse modo, uma ação com base numa decisão de consciência ou por convicção, nunca encontraria justificação se configurasse um ilícito penal, mesmo que a conduta do agente não configure em lesão de direito de terceiros, posto que o direito à vida, à integridade física, a saúde e outros direitos mais, prevaleceriam sobre os demais. Isso não implica dizer que se deva estabelecer privilégios a esses direitos fundamentais, mas sobretudo porque tratam-se de direitos coletivos que representam nada mais nada menos do que direitos individuais de cada ser humano. Independentemente deste argumento, há que se levar em conta sempre os interesses em conflito (dignidade humana), partindo sempre dos critérios constitucionais definidos para casa caso em concreto.

Não é por outra razão que o princípio da culpabilidade se orienta no princípio da dignidade humana, resultado de um Estado democrático de direito que têm como máxima o respeito

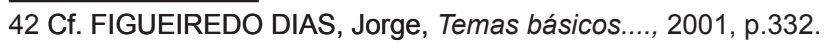


pelo ser humano. Mas essa dignidade humana «exige e oferece ao indivíduo a possibilidade de evitar a pena comportandose segundo o Direito». ${ }^{43}$ A culpa para determinação da pena consiste no total de pressupostos subjetivos da punibilidade e na responsabilidade do autor pelo injusto culpável praticado, bem como pelo seu comportamento prévio e posterior ao fato praticado, incluindo um conjunto de fatores dos quais se deriva o grau de reprovabilidade do fato para a determinação da pena. A sentença penal não condena a integridade da pessoa, mas sim a conduta do indivíduo que agiu num momento crítico da sua vida. ${ }^{44}$ Assim pune-se o agente pela sua conduta e não $o$ indivíduo falível atrás da sua infração. É a censurabilidade do fato que exprime uma contradição entre a vontade do agente e a vontade da norma penal. E isto, é expressão de indisciplina social, de rebeldia. ${ }^{45}$

A culpabilidade é o resultado de uma censura ao indivíduo, porque o seu comportamento externo é a revelação de sua personalidade, a revelação de seu psiquismo. Essa revelação obtém-se mercê da análise da personalidade do sujeito, de sua normalidade psíquica, da qualidade dos motivos, de sua força determinadora das circunstâncias em que a decisão foi tomada. Sobre a culpabilidade, ensina, Toledo, que «age culpavelmente aquele que, numa situação dada, submete-se a estímulos e impulsos orientados para o crime, deixando de opor-lhes suficientemente os meios de resistência de que dispunha, adquiridos no aprendizado da existência comunitária». ${ }^{46}$

O Direito Penal não pode ser tido como uma mera ciência de proteção de interesses objetivos e formais, pelo contrário, o Direito Penal não é apenas um catálogo que descreve os crimes

43 Cf.PUIG, Santiago Mir, Derecho Penal - Parte general. 5a ed. Barcelona: 1998, p. 97.

44 Cf. TZITZIS, Stamatios, Filosofia Penal. Trad. Mário Ferreira Monte. Portugal: Coleção IVS Commvne, 1994, p. 20.

45 Cf. COSTA JÚNIOR, Paulo José da, Direito Penal da Culpa. Ciência Penal - Doutrina - Jurisprudência - Legislação. Ano II, no 1 - 1975, p. 71-72.

46 Cf. TOLEDO, Francisco de Assis, O Erro no DireitoPenal. São Paulo: Saraiva, 1989, p. 19. 
e penas, mas sim e substancialmente o sustentáculo da ordem e garantia dos princípios fundamentais da vida organizada em sociedade, e para que o Direito Penal possa cumprir sua relevante finalidade social, suas normas deverão ser sentidas e acima de tudo compreendidas e respeitadas por todos os seres sociais. ${ }^{47}$

O que não é aceitável é ver terrorristas praticando as maiores atrocidades em prol de um fanatismo religioso, pessoas que praticam rituais de assassínios em virtude de suas seitas, a recusa das testemunhas de Jeová à prática de um exame clínico qualquer, ou mesmo a realização de uma transfusão de sangue que possa resultar perigo à vida de outrem, terem justificadas as suas condutas, quando na verdade lesionaram direito à vida, a integridade física, e a dignidade humana de terceiros, vez que estes indivíduos serviram tão somente de meios para a realização das suas convicções e consciência, indo de encontro ao imperativo categórico de Kant: «em tudo o que o indivíduo faz deve sempre tratar a si mesmo e a seus semelhantes como fim e nunca como meio».48

\section{CONCLUSÃO}

Percebe-se que em alguns países europeus tem sido dada alguma relevância no ordenamento jurídico-penal à regra de que a responsabilidade do agente pode ser de alguma forma mitigada em nome do argumento de que ele se limitou a seguir às suas convicções ou a sua consciência de acordo com as normas da sua religião, as suas ideologias, sua cultura, etc. O problema, em nossa opinião, continua a ser a necessidade de definição dos limites ao direito de liberdade de consciência, além da necessidade de estabelecer-se uma clara distinção entre uma decisão de consciência e uma decisão por convicção, e o de se saber qual o peso concreto dessa relatividade dos juízos, como pretendia Radbruch.

47 Cf. AMERICANO, Odin, Da Culpabilidade Normativa - Estudos de Direito e Processo Penal em homenagem a Nélson Hungria. São Paulo: Forense, 1962, p. 359.

48 Cf. KANT, Immanuel, Fundamentação da metafísica dos costumes e outros escritos, trad. de Leopoldo Holzbach, São Paulo: Martin Claret, 2004, p. 52. 
Os princípios da dignidade da pessoa humana e da igualdade não são valores relativizáveis. Tais princípios devem soprepor-se à certas convicções, obrigações, crenças e fé das pessoas pertencentes a uma dada comunidade étnico-cultural, ou a uma dada religião, ou a uma certa ideologia política-filosófica, pois o direito à liberdade de consciência, embora esteja diretamente relacionado com o princípio da dignidade da pessoa humana não implica uma derrogação do dever de obediência à lei. Uma simples convicção política, religiosa, ideológica, social ou filosófica, não possui o condão de afastar a tipicidade da conduta jurídico-penal, nem mesmo pode ser invocada como causa de exclusão da culpa.

Considerando que a liberdade individual encontra o seu limite na liberdade dos outros indivíduos; que a responsabilidade da pessoa emana do caráter e dos valores da vida em sociedade; que a espiritualidade é um nível superior próximo do sagrado, e que a consciência é um sentimento de si mesmo, da retidão e da justiça, então podemos concluir que independe o fato de o indivíduo ser um seguidor de uma doutrina religiosa qualquer, ou ser partidário de uma certa ideologia política, independentemente da etnia, do grupo a que pertence, da língua por ele falada, o quadro de princípios ou valores é sempre o mesmo, decorre sempre da natureza do próprio homem. A liberdade positiva do homem, já afirmava Rosseau e também hoje confirma Figueiredo Dias, ${ }^{49}$ não pode ser uma liberdade absoluta, posto que o homem para viver harmoniosamente em sociedade com outros seres sociais, rege-se pelas leis e depende delas. Se o homem social pretende ter liberdade total, quer no modo de agir e pensar, então ele terá de adotar um outro modo de vida que não seja o de viver em comunidade com outros semelhantes, porque viver em sociedade requer uma concepção do sistema social como um todo, como um conjunto consistente de códigos e procedimentos que se aplicam imparcialmente a todos os membros.

49 Cf. ROSSEAU, Jean Jacques, O Contrato Social e outros escritos. São Paulo: Cultrix, 2001.No mesmo diapasão, FIGUEIREDO DIAS, Jorge, Liberdade, Culpa, Direito Penal. Coimbra: Editora Coimbra, 1995, p.145. 
Abstract: In some european countries have been given some relevance in the legal-criminal figures to author of conscience and author of conviction, because of the constitutional guarantee of freedom of conscience. One of the problems surrounding the issue under examination is to try to know what are the limits of freedom of conscience in the face of an injury to a legal right embodied in the fundamental right of another person, even if an action based on a decision conscience or conviction can find a set justification when a criminal offense?

Keywords: Conscience. Conviction. Right. Freedom. Guilt. Criminal offense. Justification.

\section{REFERÊNCIAS}

AMERICANO, Odin. Da Culpabilidade Normativa - Estudos de Direito e Processo Penal em homenagem a Nélson Hungria. São Paulo: Forense, 1962.

CORREIA, Eduardo. Direito Criminal. Vol.II. Coimbra: Almedina, 1965.

COSTA JÚNIOR, Paulo José. Direito Penal da Culpa. Ciência Penal Doutrina Jurisprudência - Legislação. Ano II, no 1, 1975.

FIGUEIREDO DIAS, Jorge, O Problema da Consciência da Ilicitude em Direito Penal. Coimbra: Editora Coimbra, 1978.

Editora Coimbra, 2001 , Jorge. Temas Básicos da Doutrina Penal. Coimbra: , Jorge. Liberdade, Culpa, Direito Penal. Coimbra:

Editora Coimbra, 1995.

KANT, Immanuel. Fundamentação da metafísica dos costumes e outros escritos, trad. de Leopoldo Holzbach, São Paulo: Martin Claret, 2004.

1984. , Immanuel. Crítca da razão prática, trad. A. Morã, Edições 70,

PORTUGAL. Constituição da República Portuguesa Actualizada. Coimbra: Editora Almedina, 1998.

PUIG, Santiago Mir. Derecho Penal - Parte general. 5ª ed. Barcelona: 1998. 
RADBRUCH, Gustav. Filosofia do Direito. Coimbra: Coleção Stvdivm. Trad. Cabral de Moncada, Arménio Amado Editora, 1974.

, Gustav. El delincuente por Convicción. Revista Eletrônica de

Ciência Penal Y Criminologia, n 5. Trad. Guzmán Dalbora e José Luís, 2005.

ROXIN, Claus. A culpabilidade e sua exclusão no Direito Penal. Revista Brasileira de Ciências Criminais. n 46. São Paulo: Revista dos Tribunais, 2004.

ROSSEAU, Jean Jacques. O Contrato Social e outros escritos. São Paulo: Cultrix, 2001.

SILVA DIAS, Augusto. A Relevância Jurídico Penal das Decisões de Consciência. Coimbra: Almedina, 1986.

STEINMETZ, Wilson António, Colisão de direitos fundamentais e princípio da proporcionalidade, Porto Alegre: Livraria do Advogado, 2001.

TOLEDO, Francisco de Assis. O Erro no DireitoPenal. São Paulo: Saraiva, 1989.

TZITZIS, Stamatios. Filosofia Penal. Trad. Mário Ferreira Monte. Portugal: Coleção IVS Commvne, 1994.

\section{JURISPRUDÊNCIA}

BRASIL, Tribunal de Justiça de Santa Catarina. Ac no 2002.011237-8 Relator:Monteiro Rocha. 17/10/2002.

\section{WEBGRAFIA}

http://sol.sapo.pt/blogs/mjcr/default.aspx.

http://www.gddc.pt/direitos-humanos/textos-internacionais-dh/regionais. html.

http://www.gddc.pt/direitos-humanos/index-dh.html. 